E Isevier E ditorial(tm) for J ournal of Development E conomics

Manuscript Draft

Manuscript Number:

Title: Consumption, and Macroeconomic Policies: Theory and Evidence from Developing Countries

Article Type: Full Length Article

Keywords: Consumption, permanent vs. transitory effects, macroeconomic policies, income effect, cost effect

Corresponding Author: Dr. Magda Kandil International Monetary Fund

O ther Authors: Ida A. Mirzaie, PhD J ohn Carroll University 


\title{
Consumption and Macroeconomic Policies: Theory and Evidence from Developing Countries
}

\author{
by* \\ Magda Kandil * \\ and \\ Ida Aghdas Mirzaie ** \\ *International Monetary Fund \\ 700 Nineteenth St. \\ Washington D.C. 20431 \\ ** Department of Economics and Finance \\ John Carroll University \\ 20700 North Park Boulevard \\ University Heights, OH 44118-4881 \\ June 16, 2004
}

*The views in this paper are those of the authors and should not be interpreted as those of the International Monetary Fund. 


\begin{abstract}
The paper examines determinants of private consumption in a sample of developing countries. The empirical model includes income, a proxy for the cost of consumption, and the exchange rate. Anticipated movements in these determinants are likely to affect planned consumption, while unanticipated changes determine cyclical consumption. Fluctuations in private consumption are mostly cyclical with respect to income and to a lesser extent the exchange rate. Consumption increases with income and decreases in the face of a higher cost. Currency fluctuations have mixed results on private consumption. As for the effects of domestic policies, fiscal policy has a limited and sometimes a negative effect on private consumption. Monetary growth, in contrast, stimulates an increase in private consumption. This evidence supports the calls to decrease the role of government and enhance the role of monetary policy to stimulate private activity in developing countries.
\end{abstract}




\section{Contents}

$\begin{array}{llr}\text { I Introduction } & 4\end{array}$

II Literature Review $\quad 6$

$\begin{array}{ll}\text { III Theoretical Background } & 7\end{array}$

$\begin{array}{ll}\text { IV Empirical Models } & 11\end{array}$

IV-A A Structural Representation of Private Consumption . . . . . . . . . . . . 11

IV-B A Reduced-Form Representation of Private Consumption . . . . . . . . . . . 13

$\begin{array}{ll}\text { V Empirical Results } & 14\end{array}$

$\begin{array}{ll}\text { VI Conclusion } & 17\end{array}$ 


\section{Introduction}

Consumption spending is a major component of aggregate demand. ${ }^{1}$ To what extent private consumption varies with aggregate economic conditions in developing countries? A positive cyclical response of private consumption to real growth is desirable. It indicates a reduction in private consumption with a decline in real growth. This positive correlation reduces pressure on price inflation given constraints on the supply side. Further, this positive response points to the need for policy intervention to stimulate economic conditions during periods of a slowdown. It is, therefore, necessary to evaluate developments in private consumption with major policy tools: fiscal policy, monetary policy, and exchange rate policy. Nonetheless, researchers have not analyzed thoroughly determinants of consumption spending in many developing countries. Financial markets and credit availability are at different stages in developed and developing countries, necessitating different treatments in modelling and analyzing private consumption. In addition, data availability is very limited for developing countries. Our research aims at bridging the gap in the empirical literature by analyzing determinants of consumption in developing countries.

In theory, consumption spending is likely to vary with current income, the real interest rate, and steady state income. Using a rational expectation model, we decompose determinants of consumption into anticipated and unanticipated components. This decomposition aims at separating fluctuations in planned consumption in the face of anticipated forecasts from cyclical consumption that varies in the face of unanticipated shifts. The anticipated component varies with permanent income. The cyclical component varies with transitory random fluctuations. Since the nominal interest rate may be fixed in developing Countries, we use the inflation rate to indicate decisions on the intertemporal substitution of consumption for savings. Higher inflation prompts agents to increase savings and decrease consumption.

\footnotetext{
${ }^{1}$ Table 1 presents the shares of private consumption to GDP for three distinct years over time.
} 
We will study how consumption spending varies with output growth and price inflation in a sample of Middle Eastern countries. Given the dependency of many Middle Eastern countries on imports, we add the exchange rate to this model to study the effects of fluctuations in the exchange rate on real consumption. Currency appreciation would make imports cheaper and divert private consumption away from non-tradables towards tradable goods. ${ }^{2}$

We then analyze the role of stabilization policies, including both fiscal and monetary policies, in affecting planned and cyclical consumption. ${ }^{3}$ We substitute changes in monetary policy and government spending into the empirical model explaining private consumption to verify the direct effect of stabilization policies on private consumption. Anticipated changes in policy variables are likely to determine the steady state income. We will investigate if consumption moves with anticipated changes in the money supply, government spending, and the real exchange rate. In addition, one expects that transitory shocks in the money supply and government spending will determine cyclical income, price inflation and in turn the real interest rate in the short run. The results establish channels through which policy makers may target planned and cyclical consumption.

Countries included in the study are Algeria, Egypt, Iran, Jordan, Libya, Oman, Pakistan, Syria, and Tunisia. The sample period of investigation varies based on data availability. The investigation will evaluate the final findings from a regional standpoint to shed light on the cross regional similarities and the role of policy makers in determining and stabilizing consumption in a sample of developing Countries.

The remainder of the paper is organized as follows. Section II provides a literature review.

\footnotetext{
${ }^{2}$ This channel focuses on the relative prices of tradables and non-tradables. Private consumption may not be affected if consumers substitute imported goods for consumption of domestically produced goods. Other researchers have focused, however, on the contractionary effect of currency depreciation on real income and, therefore, private consumption. According to Diaz-Alejandro (1963), devaluation transfers real income from workers to producers of exports and non-tradables. The latter group has a smaller marginal propensity to consume. Along the same lines, Krugman and Taylor (1978) and Barbone and Rivera-Batiz (1987) have formalized several channels of the contractionary effects of devaluation on private consumption.

${ }^{3}$ For related references, see Heller and Starr (1979), Reinhart and Vegh (1995), Sarno and Taylor (1998), Hussein and de Mello (1999), and Yin and Wan (2002).
} 
Section III introduces a theoretical background to model private consumption. Section IV outlines the empirical models. Section V presents empirical results. The summary and conclusion are presented in Section VI.

\section{Literature Review}

Factors determining consumption are as follows: Income, which can be decomposed into a permanent (anticipated) component, and the shocks that vary with the cycle. The cost of borrowing, i.e., the interest rate is likely to determine the intertemporal substitution between current consumption and future consumption (savings). Researchers have noted, however, more dominant effects of income on consumption spending. Hence, fluctuations in the interest rate, say with monetary policy, may or may not affect consumption in the short run.

Theoretical developments have incorporated rational expectations to formulate agents strategy regarding consumption in relation to permanent income. Empirical research has challenged, however, the steady nature of consumption in relation to permanent income. Hall (1978) indicates that consumption expenditure follows a random walk, which implies that only unexpected policy changes can affect consumption, given knowledge of last periods consumption. Heller and Starr (1979), Flavin (1981), Hall and Mishkin (1982), Campbell and Mankiw (1989) present empirical findings that suggest the Rational Expectation Permanent Income Hypothesis does not hold because consumption displays an excess dependence on current income. Campbell and Mankiw (1989, 1990, and 1991) show that for nondurable and service consumption, the elasticity of intertemporal substitution is basically zero. It is expected, however, that the excess dependence of consumption on current income due to capital imperfection and credit rationing is more pronounced in developing societies due to capital imperfection and credit rationing. As Kaynak, Kucukemiroglu, and Ozmen (1995) state, people tend to use more cash in developing countries rather than using credits. Yet, 
for these countries, the link between consumption and the real interest rate may exist for durable consumption. If true consumers may indeed adjust their consumption allocations in response to changes in real interest rates.

In addition, the consumption level in Middle Eastern countries maybe influenced by the real value of their currency via the effect on import prices and price inflation. According to Diaz-Alejandro (1963), devaluation may lead to a reduction in consumption and real income. He uses a three-good model of exportable, importable, and home goods with relatively price-inelastic exports and imports and consumption functions displaying higher saving propensities for non-wage earners. The underlying mechanisms behind the devaluation impact on consumption lies in the transfer of real income from workers to producers who have higher propensities to save out of factor income. Krugman and Taylor (1978) and Barbone and Rivera-Batiz (1987) have formalized the same view. The Krugman-Taylor paper formalizes several channels of contractionary influences, which are likely to prevail, particularly in developing countries. Krugman and Taylor discuss that devaluation will lead to a reduction in real output if devaluation raises prices of traded goods relative to home goods, giving rise to windfall profits in export and import-competing industries. If money wages lag the price increase and if the marginal propensity to save from profits is higher than from wages, national savings will go up, and consumption and real output consequently will decrease.

\section{Theoretical Background}

In the real world, stochastic uncertainty may arise in the macroeconomy. Economic agents are assumed to be rational. Accordingly, rational expectations distinguish planned behavior from cyclical behavior in the face of random transitory fluctuations. Rational agents engage in a process of forecasting macroeconomic fundamentals. This forecast represents the steady state trend of the macroeconomy. Random fluctuations are assumed to be realized around this steady state trend. 
The demand side of the economy is specified using standard IS-LM equations with a modification for an open economy. The specifications below describe equilibrium conditions in the Goods and Money markets. All coefficients are positive. The subscript $t$ denotes the current value of the variable.

$$
\begin{aligned}
c_{t}= & c_{0}+c_{1} y_{d t}+c_{2} i n t_{t}+c_{3} \text { rer }_{t}, \\
& 0<c_{1}<1, \quad c_{2}, c_{3}>0 \\
i n t_{t}= & r_{t}+E_{t}\left(p_{t+1}-p_{t}\right) \\
y_{d t}= & y_{t}-t_{t} \\
t_{t}= & t_{0}+t_{1} y_{t}, \quad t_{1}>0 \\
i_{t}= & i_{0}-i_{1} r_{t}, \quad i_{1}>0 \\
x_{t}= & x_{0}-x_{1} r e r_{t}, \quad x_{1}>0 \\
i m_{t}= & g_{0}+g_{1} y_{t}+g_{2} r e r_{t}, \quad g_{1}, g_{2}>0 \\
y_{t}^{D}= & c_{t}+i_{t}+g_{t}+x_{t}-i m_{t} \\
m_{t}-p_{t}= & m_{0}-m_{1} i n t_{t}+m_{2} y_{t}, \quad m_{1}, m_{2}>0 \\
y_{t}^{S}= & s_{0}+s_{1}\left(p_{t}-E_{t-1} p_{t}\right)
\end{aligned}
$$

In equation (1), real consumption expenditure, $c$, varies positively with real disposable income, $y_{d}$. Consumption varies negatively with the interest rate, int $t_{t}$. An increase in reer is consistent with currency appreciation. An appreciation of the real exchange rate decreases the cost of tradables and, therefore, consumption of non-tradables. The combined effect will depend on the elasticity of consumers' substitution between tradables and non-tradables. In equation (2), the nominal interest rate is the sum of the real interest rate, $r$, and inflationary expectation, $\left(E_{t} p_{t+1}-p_{t}\right)$, where $p_{t}$ is the aggregate price level and $E_{t}$ is agents' forecast conditional on information available at time $t$. In equation (3), disposable income is defined to be the net of real income, $y$, minus taxes, $t$. In equation (4), real taxes are specified as a 
linear function of real income. In equation (5), real investment expenditure, $i$, varies negatively with the real interest rate. In equation (6), real exports are related to an autonomous element, $x_{0}$, which rises when the income level abroad rises, and to relative prices. The negative relationship between rer and $x$, in (6), refers to the fact that when the domestic price is higher relative to foreign goods, exports will decrease. In equation (7), real imports, $i m$, are assumed to rise with the level of real income and increase with the real exchange rate of the domestic currency. Equation (8) describes the equilibrium condition in the goods market. Real government spending, $g$, is assumed to be exogenous. The total expenditure by domestic residents in real terms $y^{D}$ is the sum of real consumption expenditure $(c)$, real investment $(i)$, real government spending $(g)$, and net exports (the real value of exports, $x$, minus the real value of imports, $\mathrm{im}$ ).

Substituting all equations into the equilibrium condition for the goods market results in the expression for real income. It is a function of the exchange rate, the domestic price level, the foreign price level, and the domestic interest rate. This expression is the IS equation which describes the negative relationship between real income and the real interest rate.

In equation (9), equilibrium in the money market is obtained by equating the demand and supply of real money balances. The real money supply is determined by nominal balances, $m$, deflated by price, $p$. The demand for real money balances is positively related to real income and inversely related to the nominal interest rate.

The LM equation is determined by the equilibrium condition in the money market. It establishes a positive relationship between real income and the real interest rate. Solving for the interest rate, $\mathrm{r}$, from the LM equation and substituting the result into the IS equation results in the equation for aggregate demand.

Aggregate supply in (10) varies with determinants of the output supply in the production function, $s_{0}$, and output price surprises, $\left(p_{t}-E_{t-1} p_{t}\right)$. Rational agents forecast the aggregate price level conditional on information available at time $t-1, E_{t-1} p_{t}$. Aggregate demand shifts 
induce changes in the output price around its forecasted value. These fluctuations create output price surprises that are the domain of random unexpected shocks on the demand and supply sides of the economy.

The solution of the model decomposes each of the endogenous variables, output, price, and the interest rate into anticipated and unanticipated components. Anticipated changes are the domain of anticipated shifts in the economy that vary with agents' forecasts of macroeconomic fundamentals. Unanticipated changes are deviations around these forecasts that vary with random shocks impinging on the economic system.

Having solved for disposable income and the interest rate, private consumption is solved for. According to this solution, planned private consumption varies with anticipated changes in policy variables, government spending and the money supply, as well as anticipated changes in the exchange rate. Cyclical consumption varies unexpectedly with unanticipated changes in these variables.

An increase in government spending increases income and the interest rate. The effects of an increase in government spending on private consumption is likely to depend on the marginal propensity to consume out of income, $c_{1}$, and the sensitivity of private consumption to a change in the interest rate, $c_{3}$, as well as on the relative effects of government spending on income and the interest rate. If the income channel dominates, an increase in government spending increases disposable income and, hence, private consumption. In contrast, if the interest rate channel dominates, an increase in government spending increases the interest rate and decreases private consumption.

An increase in the money supply increases income and decreases the real interest rate (the liquidity effect). Theoretical developments have established, however, the positive effect of an increase in the money supply on inflationary expectations (the Fisher effect). If the Fisher effect dominates the liquidity effect, the nominal interest rate may be rising following an increase in the money supply. The effect of an increase in the money supply on private 
consumption will depend, therefore, on the marginal propensity to consume out of income, $c_{1}$, the sensitivity of private consumption to a change in the interest rate, $c_{3}$, and the relative effects of the money supply on income and the interest rate.

An appreciation of the real exchange rate decreases the cost of imports. As the demand for imports increases, private consumption of non-tradables decreases. The final effect on consumption will depend on the relative increase in tradable consumption compared to the reduction in non-tradable consumption.

\section{Empirical Models}

The empirical investigation analyzes annual time-series data of private consumption in eight countries in the Middle East: Algeria, Egypt, Iran, Jordan, Libya, Oman, Pakistan, Syria, and Tunisia. Data for most countries range from 1963-2002. For Algeria and Tunisia, the sample period extends through 2003. For Oman, the sample period is 1967-2002. For data definition and sources, see Appendix B.

The analysis will proceed in two steps. In the first step, we estimate a structural equation that replicates equation (1). Real GDP is used as a proxy for income. Private consumption varies with income, the interest rate, and the real exchange rate. Given constraints on the interest rate data, we substitute price inflation as a proxy for the cost of consumption. Higher inflation decreases income and increases agents' desire to accumulate additional savings to hedge against inflation. In the second step, we substitute the money supply and government spending for income and the interest rate. The results will identify the effect of stabilization policies on the biggest component of aggregate demand.

\section{IV-A A Structural Representation of Private Consumption}

Private consumption varies with income, the interest rate (or price), and the real exchange rate. Assuming rational expectation, each variable can be further decomposed into antici- 
pated and unanticipated components.

Having tested for non-stationarity, the empirical model is specified in first-difference form as follows: ${ }^{4}$

$$
\begin{aligned}
& D c_{t}=A_{0}+A_{1} E_{t-1} D y_{t}+A_{2}\left(D y_{t}-E_{t-1} D y_{t}\right) \\
& +A_{5} E_{t-1} \operatorname{Dir}_{t}+A_{6}\left(\operatorname{Dir}_{t}-E_{t-1} \operatorname{Dir}_{t}\right)+A_{7} E_{t-1} \operatorname{Drer}_{t}+A_{8}\left(\operatorname{Drer}_{t}-E_{t-1} \text { Drer }_{t}\right) \\
& +A_{7} E C_{t-1}+\nu_{c t}
\end{aligned}
$$

Here, $c_{t}$ is the $\log$ value of real private consumption, where $D($.$) is the first-difference op-$ erator. The log values of income, the interest rate, and the exchange rate are denoted by $y_{d t}, i r_{t}$ and $r e r_{t}$. The change in each of these variables is decomposed into anticipated and unanticipated components, where $E_{t-1}$ denotes expectations at time $t-1 .^{5}$

Since the model is estimated in first-difference form, we should test if the non-stationary dependent variable is jointly cointegrated with all non-stationary right-hand side variables. Given evidence of cointegration (see Table A2), the error correction term is included in the empirical model. ${ }^{6}$ The unexplained residual of the model is denoted by $\nu_{c t}$.

In the first model, real consumption varies with real GDP growth, the change in the real interest rate, and fluctuations in the real exchange rate. Real consumption expenditure varies positively with real income and negatively with the interest rate. Higher interest rate increases incentives to save, decreasing private consumption. An increase in the real exchange indicates currency appreciation. An appreciation of the exchange rate decreases the cost of

\footnotetext{
${ }^{4}$ For details, see Kwiatkowski e. al. (1992). To select lags for the KPSS test, we follow the suggestions of Newey and West (1994). Non-stationarity indicates that the series follows a random walk process. Upon first-differencing, the resulting series is stationary. Table A1 in the appendix summarizes the results of non-stationarity.

${ }^{5}$ We test for the endogeneity of the explanatory variables in the model (see Table A3). Given evidence of endogeneity, the forecast equations account for lagged values of variables proven to be statistically significant.

${ }^{6}$ As long as there exists at least one cointegrating vector, it is necessary to control for this long-run relationship in the empirical model using stationary data. The error correction term captures deviation around the long-run trend, i.e., the lagged value of the residual from regressing the non-stationary dependent variable on the non-stationary variables in the model.
} 
tradables and, therefore, consumption of non-tradables. The combined effect will depend on the elasticity of consumers' substitution between tradables and non-tradables. Interest rate data are available for three countries only: Egypt, Jordan, and Pakistan. For the remaining countries, we substitute price inflation for the real interest rate. Higher inflation increases the cost of consumption and, therefore, incentives for savings.

To establish robustness and draw further insights, we estimate another version of the empirical model allowing for variation in data measures. Nominal consumption varies with nominal GDP, the nominal interest rate, and the nominal exchange rate, or nominal consumption varies with real GDP, price, and the nominal exchange rate.

\section{IV-B A Reduced-Form Representation of Private Consumption}

In the second step of empirical investigation, we substitute government spending and the money supply for income and the interest rate in the empirical model (11). Accordingly, the following empirical model is estimated:

$$
\begin{aligned}
D c_{t}= & B_{0}+B_{1} E_{t-1} D g_{t}+B_{2}\left(D g_{t}-E_{t-1} D g_{t}\right)+B_{3} E_{t-1} D m_{t}+B_{4}\left(D m_{t}-E_{t-1} D m_{t}\right) \\
& +A_{5} E_{t-1} \text { Dreer }_{t}+A_{6}\left(\text { Dreer }_{t}-E_{t-1} \text { Dreer }_{t}\right)+A_{7} E C_{t-1}+\nu_{c t}
\end{aligned}
$$

Real consumption varies with real government spending, real money supply and the real exchange rate. The log values of real government spending and the real money supply are denoted by $g_{t}$ and $m_{t}$. The growth of government spending and the money supply are decomposed into anticipated and unanticipated components. To establish robustness and draw further insights, we estimate another version of the empirical model allowing for variation in data measures. Nominal consumption varies with nominal government spending, nominal money, and the nominal exchange rate. 


\section{Empirical Results}

The empirical investigation analyzes time-series data of private consumption in a sample of MENA countries. The results of estimating the empirical model for real consumption as a function of real GDP, real interest rate, and the real exchange rate are presented in Table $2 \mathrm{~A}$.

Anticipated real GDP growth is not statistically significant to determine real consumption. This evidence challenges the implications of the permanent income hypothesis. In contrast, the cyclicality in real consumption is evident by the statistically significant effect of unanticipated real GDP growth on the growth of real consumption. The effect of the interest rate channel appears also cyclical in decreasing real consumption in Pakistan. There is no evidence of a long lasting effect of anticipated changes in the interest rate on real consumption. The cyclicality of real consumption is also evident in the face of fluctuations in the real exchange rate. Unanticipated appreciation decreases consumption, indicating a higher desire to increase savings, offsetting the positive effect of an increase in imports.

The evidence in Table 2B indicates fluctuations in real consumption in the face of anticipated and unanticipated components of real GDP growth, price inflation, and the change in the real exchange rate. The evidence remains robust regarding the insignificant effect of anticipated real growth on private consumption, challenging the implications of the permanent income hypothesis. In contrast, the cyclicality of real consumption in relation to the unanticipated growth of real income is evident and significant in Algeria, Libya, Syria, and Tunisia. In general, price inflation appears insignificant in determining real consumption, except for one case. In Syria, anticipated price inflation stimulates an increase in real consumption. ${ }^{7}$ In general, fluctuations in the real exchange rate appear insignificant in determining real consumption. One exception is in the case of Iran where unanticipated appreciation leads

\footnotetext{
${ }^{7}$ Historically, Syria has enjoyed a relatively moderate price inflation, or even negative inflation some time, compared to other developing countries. Accordingly, anticipated inflation stimulates an increase in the growth of private consumption.
} 
to a significant increase in real consumption of imported goods.

Table 3A provides the evidence of estimating the empirical model explaining the growth of nominal consumption as a function of the growth of nominal income, the increase in the interest rate, and the appreciation of the nominal exchange rate.

There is a significant positive effect of anticipated nominal income growth on nominal consumption. Hence, there is a long lasting increase in nominal consumption with anticipated price inflation that appears to be statistically significant in Jordan and Pakistan. The cyclicality of private consumption is also evident and significant in the face of unanticipated fluctuations in income in Egypt, Jordan, and Pakistan. Anticipated nominal interest rate increases nominal consumption significantly in Egypt. Hence, the inflationary component moves the trend component of the nominal interest rate and nominal consumption over time. The cylicality of the interest rate has, however, a significant negative effect on private consumption in Egypt. This evidence indicates an increased desire to hold higher savings as the nominal interest rate increases unexpectedly. There is also evidence of an increase in domestic savings as the currency appreciates in value unexpectedly. This is evident by the negative and statistically significant effect of unanticipated currency appreciation on private consumption in Egypt.

For other countries, where data are not available for the nominal interest rate, we estimate nominal consumption as a function of real GDP (scale effect), price (cost effect), and the nominal exchange rate. The results are presented in Table 3B. Anticipated growth in real GDP is significant in increasing the growth of nominal consumption in Oman. This is consistent with a permanent income effect on private consumption where higher planned income stimulates spending. The cyclicality of private consumption remains evident and significant in the face of unanticipated growth in real income in Libya, Syria, and Tunisia. The evidence, in general, indicates limited significant effects of fluctuations in the exchange rate on private consumption. In one exception, Tunisia, unanticipated currency appreciation 
decreases private consumption significantly. Higher currency appreciation increases savings and decreases demand for private consumption.

Table 4 presents the results of estimating real consumption as a function of real government spending, real money, and the real exchange rate. There is no evidence of a long lasting effect of anticipated growth of government spending on private consumption. The cyclical effect of unanticipated government spending on private consumption is evident and significant in Tunisia. There is, however, evidence of more cyclicality in private consumption in the face of unanticipated monetary shocks, as evident by the positive and statistically significant effect in Iran, Syria, and Tunisia. Fluctuations in the real exchange rate appear mostly insignificant on private consumption. The only exception is unanticipated appreciation in Iran which increases private consumption of imports significantly.

The last model in Table 5 presents the results of estimating nominal consumption as a function of nominal government spending, nominal money, and the nominal exchange rate. In Libya and Tunisia, anticipated government spending has a positive and statistically significant effect on nominal consumption. Hence, the inflationary component establishes a long-term association between the trend components of government spending and private consumption. Unanticipated growth in government spending increases private consumption significantly in Oman and Tunisia. There is evidence, however, of a significant crowding out of private consumption in the face of higher government spending, both anticipated and unanticipated in Egypt. Higher government spending increases the budget deficit and raises the interest rate. Higher deficit increases uncertainty and, therefore, incentives for savings. Similarly, higher interest rates increase incentives for savings and decrease consumption.

The effects of monetary growth appear less pervasive compared to the previous model. Anticipated monetary growth increases private consumption significantly in Jordan and Oman. Similarly, unanticipated monetary growth increases private consumption significantly in Tunisia. In general, fluctuations in the exchange rate are not statistically sig- 
nificant to determine private consumption. Unanticipated currency appreciation increases private consumption significantly in Iran and Syria. This is consistent with the effect of currency appreciation in stimulating imports. In contrast, currency appreciation (depreciation) has a significant negative (positive) effect on the growth of private consumption in Egypt. Depreciation raises prices, increasing the growth of nominal consumption.

\section{Conclusion}

The analysis of this paper has focused on a sample of nine developing countries. Theory has distinguished between cyclical and planned fluctuations in private consumption. Planned consumption is in response to anticipated changes in economic variables. In contrast, random transitory fluctuations determine cyclical consumption.

Our model specification is based on a structural representation in which private consumption varies with income, the interest rate, and the exchange rate. Private consumption is expected to vary positively with income. The interest rate in the model specification approximates the cost of consumption. Where interest rate data are not available, price inflation is used to measure the cost of consumption. Higher interest rate and/or higher price inflation increase the cost of consumption and raise incentives for savings. Currency appreciation decreases the cost of imports and, therefore, consumption of non-tradables.

Using rational expectation, we decompose determinants of consumption: income, the interest rate or price inflation and the exchange rate into anticipated and unanticipated components. The results, in general, discount the relevance of the permanent income hypothesis. Fluctuations in private consumption are mostly cyclical with respect to income. Consumption increases with income. The procyclical nature of consumption reduces pressure on price inflation given constraints on the supply side of many developing countries. This evidence points to the need for policy intervention to stimulate economic conditions during periods of slowdown. 
Consumption decreases in the face of a higher cost, as evident by fluctuations in response to a higher interest rate and/or a higher price inflation. Currency fluctuations have mixed results on private consumption. A positive response to currency appreciation indicates a dominant increase in imports. In contrast, a negative response indicates a dominant reduction in consumption of nontradables.

In the last step of empirical investigation, we estimate a reduced-form equation of private consumption. The growth of government spending and the money supply replace income and the interest rate in the empirical model. The evidence indicates that government spending has a limited and sometimes negative effect on private consumption. Higher government spending increases the budget deficit and uncertainty, forcing a reduction in private consumption. In contrast, monetary growth, both anticipated and unanticipated, stimulates an increase in private consumption. Monetary growth increases liquidity which finances the growth of private consumption.

Overall, the evidence sheds new light on the determinants of private consumption in a sample of developing countries and distinguishes between planned and cyclical consumption. The cyclicality of private consumption and its significant fluctuations support calls to decrease the role of government and enhance the role of monetary policy to stimulate private activity in developing countries. 


\section{Appendix A \\ Econometric Methodology}

The surprise terms that enter models (11) and (12) are unobservable, necessitating the construction of empirical proxies before estimation takes place. Thus, the empirical models include equations describing agents' forecast of the change in the log values of income, the interest rate, the exchange rate, the money supply and government spending. All variables are first-differenced to render the series stationary, as described in Table A1.

To decide on variables in the forecast equations, a formal causality test is followed. Each variable is regressed on two of its lags as well as two lags of all variables that enter the model: the change in the log value of income, the interest rate or price, and the exchange rate, in model (11), or the change in the log value of government spending, the money supply, and the exchange rate, in model (12). The joint significance of the lags is tested for each variable (see Table A3). Accordingly, the forecast equations account for the lags of variables proven to be statistically significant.

Subtracting the above forecasts from the actual change in the variable results in surprises that enter the empirical model. To obtain efficient estimates and ensure correct inferences (i.e., to obtain consistent variance estimates), the empirical models are estimated jointly with a forecast equation for each anticipated regressor, following the suggestions of Pagan (1984 and 1986).

To account for endogenous variables, instrumental variables are used in the estimation of the empirical models. The instrument list includes four lags of all variables in the model: price, the interest rate, income, money, government spending and the exchange rate. In a few cases, the number of lags has been modified until the estimation did converge. The paper's evidence remains robust with respect to modifications that alter variables or the lag length in the forecast equations and/or the instruments list.

Following the suggestions of Engle (1982), the results of the test for serial correlation in simultaneous equation models are consistent with the presence of first-order autoregressive errors. To maintain comparability, it is assumed in all models that the error term follows an $\mathrm{AR}(1)$ process. The estimated models are transformed, therefore, to eliminate any possibility of serial correlation. The estimated residuals from the transformed models have zero means and are serially independent. 


\section{Appendix B \\ Data Sources}

The sample period for investigation varies based on data availability as follows: Algeria (1963-2003), Egypt (1963-2002), Iran (1963-2002), Jordan (1966-2000), Libya (1963-2002), Oman (1967-2002), Pakistan (1963-2002), Syria (1964-2000), and Tunisia (1963-2003).

Variables used in investigation are as follows:

1. Interest Rate: Discount rate, IFS, 60..ZF.

2. Private Consumption: Household consumption expenditure, IFS, 96F..ZF.

3. Broad Money: WEO, WFMB.

4. General Government Expenditure and Net Lending: WEO. WGCENL.

5. Exchange Rate: National currency per US dollar, WEO, WENDA.

6. Real Exchange Rate: Real exchange rate multiplied by the U.S. CPI and divided by the developing countries CPI. The inverse measures the value of national currency in terms of dollar. An increase indicates appreciation.

7. GDP Deflator: WEO, WNGDP.

8. Nominal GDP: Gross domestic product current prices, WNGDP.

9. Consumer Price Index: WEO, WPCPI.

All nominal variables have been deflated by the GDP deflator to measure real terms.

All country variables are from the IMF, International Financial Statistics (IFS), or World Economic Outlook (WEO), except for US CPI, which is taken from the Federal Reserve Bank of St. Louis. 


\section{References}

[1] Barbone, Luca and Francisco Rivera-Batiz, "Foreign Capital and the Contractionary Impact of Currency Devaluation, with an Application to Jamica," Journal of Development Economics, (Amsterdam),(June 1987), Vol 26, pp. 1-15.

[2] Benoit, Carmichael, Sikoro Keita, and Lucie Samoson, "Liquidity Constraints and Business Cycles in Developing Countries," Review of Economic Dynamics, (1999), 2, pp. 370-402.

[3] Campbell, J. Y. and Mankiw, N. G., "Consumption and Interest Rates: Reinterpreting the Time-Series Evidence," NBER Macroeconomics Annual, (1989), (eds) O. J. Blanchard and S. Fisher, MIT Press: Cambridge.

[4] Campbell, J. Y. and Mankiw, N. G., "Permanent Income, Current Income, and Consumption," Journal of Business and Economic Statistics,(1990), 8(3), pp. 265-279.

[5] Campbell, J. Y. and Mankiw, N. G., "The Response of Consumption to Income, A Cross-Country Investigation," European Economic Review, (1991), 35, pp. 723-767.

[6] Canner, G. B. and Fergus, J. T. "The Economic Effects of Proposed Ceilings on Credit Card Interest Rates," Federal Reserve Bulletin, (1987), 73, pp. 1-13.

[7] Carmichael Benoit, Sikoro Keita, and Lucie Samoson, (1999), Liquidity Constraints and Business Cycles in Developing Countries, Review of Economic Dynamics, 2, pages 370402.

[8] Cashin Paul and C. John McDermott, (1998) Testing the Consumption-CAPM in Developing Equity Markets, International Journal of Finance and Economics, 3, pp. 127-141.

[9] Dejuan, Joseph P. and John J. Seater, "The Permanent Income Hypothesis: Evidence from the Consumer Expenditure Survey," Journal of Monetary Economics, (1999), 43, pp. 351-376.

[10] Diaz-Alejandro, Carlos F., "A Note on the Impact of Devaluation and Redistributive Effects," Journal of Political Economy, (August 1963), Vol. 71, pp. 577-580.

[11] Engle, R. R. "A General Approach to Lagrange Multiplier Model Diagnostics," Journal of Econometrics, (1982) 20, 83-104.

[12] Falvin, M. A. "The Adjustment of Consumption to Changing Expectations about Future Income," Journal of Political Economy, (1981), 89, pp. 974-1009.

[13] Friedman, M. A Theory of the Consumption Function, (1957), Princeton, NJ: Princeton University Press for National Bureau of Economic Research.

[14] Fuhrer, Jeffrey, C. "Habit Formation in Consumption and Its Implications for Monetary Policy Models," American Economic Review, June (2000). 
[15] Girardin, Eric, Lucio Sarno, and Mark P. Taylor, "Private Consumption Behavior, Liquidity Constraints and Financial Deregulation in France: A non-Linear Analysis," Empirical Economics, (2000), Vol. 25, pp. 351-368.

[16] Hahm, Joon-Ho "Consumption Adjustment to Real Interest Rates: Intertemporal substitution Revisited," Journal of Economic Dynamics and Control, pp. 293-320.

[17] Hall, R. E. "The Stochastic Implication of the Life-Cycle Permanent Income Hypothesis: Theory and Evidence," Journal of Political Economy, (1978), 96, pp. 971-87.

[18] Hall, R. E. and Mishkin, F. S. "The Sensitivity of Consumption to Transitory Income: Estimates from Panel Data on Households," Econometrica (1982), 50, pp. 461-81.

[19] Heller, W. P. and Starr, R. M. "Capital Market Imperfection, the Conumption Function, and the Effect of Fiscal Policy," Quarterly Journal of Economics, (1979), CXIII, pp. 455463.

[20] Hussein, Khaled A. and DeMello, Luiz R. Jr. "International Capital Mobility in Developing Countries: Theory and Evidence," Journal of International Money and Finance, (1999), 18, pp. 367-381.

[21] Kandil, Magda (2001), Asymmetry in the Effects of US government Spending Shocks: Evidence and Implications, The Quarterly Review of Economics and Finance, 41, pp. $137-165$

[22] Kaynak, Erdener, Orsay Kucukemiroglu and Ahmet Ozmen, "Correlates of Credit Card Acceptance and Usage in an Advanced Developing Middle Eastern Country," Journal of Services Marketing, (1995), Vol. 9, No. 4, pp. 52-63.

[23] Krugman, Paul R. and Richard E. Baldwin, "The Persistence of the U.S. Trade Deficit," Brookings Papers on Economic Activity, No. 1, pp. 1-43.

[24] Krugman and Taylor, "Contractionary Effects of Devaluation," Journal of International Economics, (1978), 8, pp. 445-456.

[25] Kwiatkowski, Denis, Peter C. B. Phillips, Peter Schmidt, and Yongcheol Shin, "Testing the Null Hypothesis of Stationarity Against the Alternative of a Unit Root: How Sure Are We That Economic Time Series Have a Unit Root?" Journal of Econometrics, 54, 1992, pp. 159-78.

[26] Leong, Kenneth and Michael AcAleer, "Testing the Life-Cycle Permanent Income Hypothesis Using Intra-Year Data for Sweden," Mathematics and Computers in Simulation, (1999), 48, pp. 551-560.

[27] Mathieson, Donald J. and Liliana Rojas-Suarez, "Financial Market Integration and Exchange Rate Policy," IMF Working Paper, (1990), WP/90/02, Washington D.C.

[28] Newey, Whitney and Kenneth West, "Automatic Lag Selection in Covariance Matrix Estimation," Review of Economic Studies, 61, pp. 631-653. 
[29] Pagan, Adrian, "Econometric Issues in the Analysis of Regressions with Generated Regressor," International Economic Review, 1984, 25, 221-47.

[30] Pagan, Adrian, "Two Stage and Related Estimators and Their Applications," Review of Economic Studies, 1986, 53, 517-38.

[31] Park, Sangkyun and Anthony P. Rodrigues, "Is Aggregate Consumer Borrowing Consistent with the Permanent Income Hypothesis?" The Manchester School, (2000), Vol. 68, No. 3, pp. 301-320.

[32] Reinhart, Carmen M. and Carlos A. Vegh, "Nominal Interest Rates, Consumption Booms, and Lack of Credibility: A Quantitative Examination," Journal of Development Economics, (1995), Vol. 46. pp. 357-378.

[33] Rodrik, Dani, (2000), "What Drives Public Employment in Developing Countries? Review of Development Economics, 4(3), pp. 229-243.

[34] Sarno, Lucio and Mark P. Taylor, "Real Interest Rates, Liquidity Constraints, and Financial Deregulation: Private Consumption Behavior in the U.K.," Journal of Macoreconomics, (1998), Vol. 20, pp. 221-242.

[35] Scott, A. "Consumption, 'Credit Crunches' and Financial Deregulation," CEPR Discussion Paper, no. 1389, (1996), London, Centre for Economic Policy Research.

[36] Yin, Zhang and Guang Hua Wan "Household Consumption and Monetary Policy in China," China Economic Review, (2002), 13, pp. 27-52.

[37] Zeldes, Stephen P. "Consumption and Liquidity Constraints: An Empirical Investigation," Journal of Political Economy, (1989), 97, pp. 305-346.

[38] Zhang Yin and Guang Hua WAN, (2002) Household Consumption and Monetary Policy in China, China Economic Review, 13, pp. 27-52. 
Table 1: Shares of private consumption to GDP

$\begin{array}{lllll} & \underline{1990} & \underline{1995} & \underline{2000} & \underline{\text { Average 1966-2000 }} \\ \text { Algeria } & 56.6 & 55.6 & 41.8 & 47.1 \\ \text { Egypt } & 71.7 & 74.2 & 76.17 & 68.1 \\ \text { Iran } & 59.9 & 47.1 & 47.7 & 52.3 \\ \text { Jordan } & 74.1 & 64.6 & 79.5 & 72.8 \\ \text { Libya } & 48.4 & 58.8 & 45.4 & 40.10 \\ \text { Pakistan } & 65.1 & 67.8 & 71.3 & 67.7 \\ \text { Syria } & 68.7 & 66.2 & 64.1 & 70 \\ \text { Tunisia } & 63.6 & 62.9 & 60.6 & 61.8 \\ \text { Oman } & 50.3 & 47.6 & 41.4 & 32.86\end{array}$


Table 2A: Nonlinear 3SLS Parameter Estimates

Model -1A: Real Consumption as a function of Real GDP, Real Interest Rate, and Real Exchange Rate

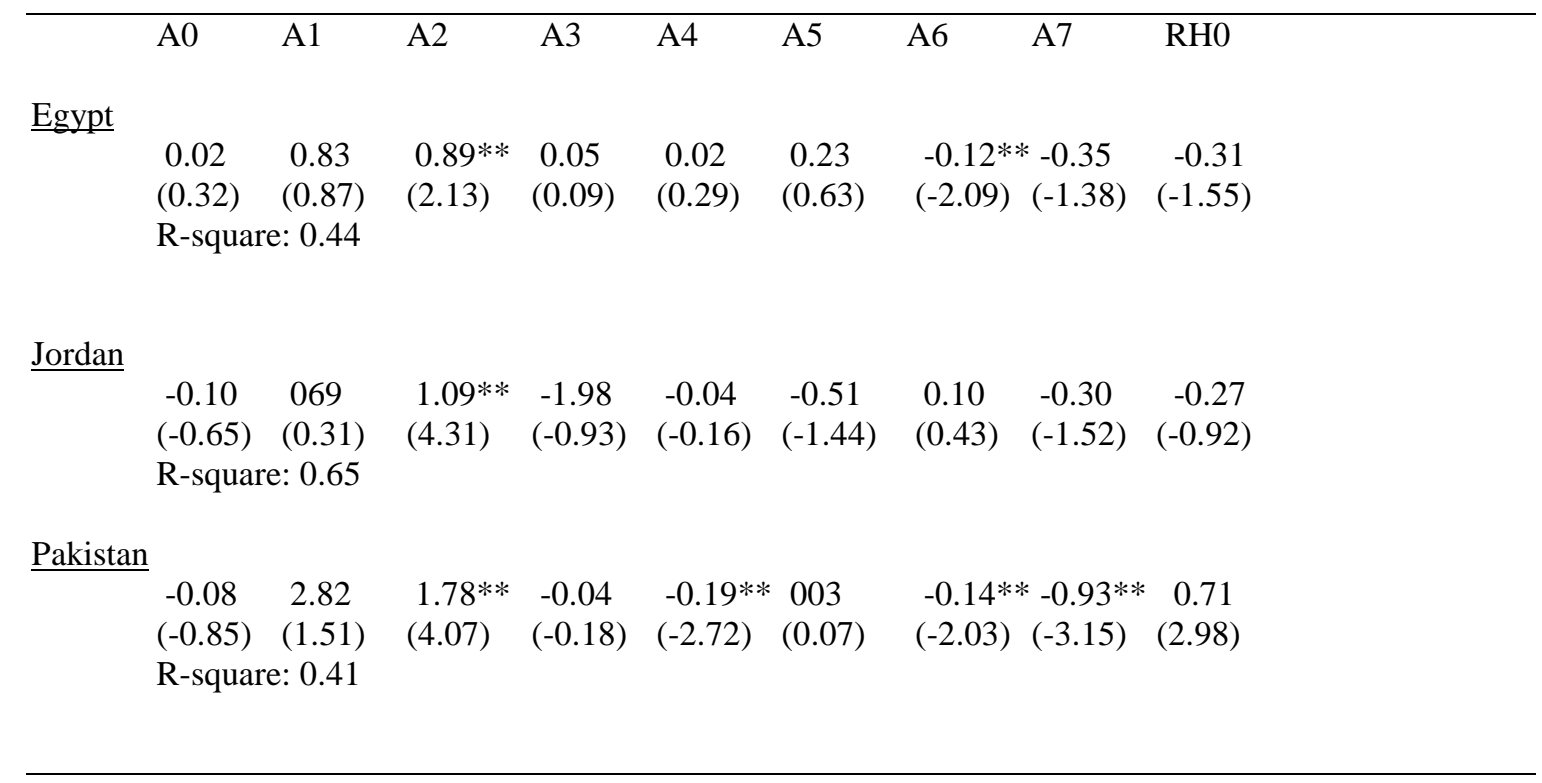

A0 Intercept

A1 Anticipated Change in Real GDP

A2 Unanticipated Change in Real GDP

A3 Anticipated Change in Real Interest Rate

A4 Unanticipated Change in Real Interest Rate

A5 Anticipated Change in Real Exchange Rate

A6 Unanticipated Change in Real Exchange Rate

A7 Error Correction

RH0 Serial correlation

** Significant at $5 \%$.

* Significant at $10 \%$.

t-ratios are in parenthesis 
Table 2B: Nonlinear 3SLS Parameter Estimates

Model -1B. Real Consumption as a function of Real GDP, Price, and Real Exchange Rate

\begin{tabular}{|c|c|c|c|c|c|c|c|c|c|}
\hline & $\mathrm{A} 0$ & A1 & A2 & A3 & A4 & A5 & A6 & A7 & RH0 \\
\hline \multicolumn{10}{|l|}{ Algeria } \\
\hline & -0.08 & 1.07 & $1.30 *$ & 0.78 & 0.30 & 0.07 & -0.06 & -0.72 & 0.36 \\
\hline & $(-0.83)$ & $(0.68)$ & (1.87) & $(1.05)$ & $(0.63)$ & $(0.16)$ & $(-0.23)$ & $(-0.99)$ & $(0.49)$ \\
\hline & R-squar & e: 0.40 & & & & & & & \\
\hline \multicolumn{10}{|l|}{ Iran } \\
\hline & 0.01 & 0.38 & 0.01 & 0.05 & -0.43 & -0.10 & $0.29 * *$ & -0.29 & -0.17 \\
\hline & $(0.13)$ & $(0.95)$ & $(0.04)$ & $(0.13)$ & $(-0.88)$ & $(-0.25)$ & $(2.47)$ & $(-1.17)$ & $(-0.58)$ \\
\hline & R-squar & e: 0.27 & & & & & & & \\
\hline \multicolumn{10}{|l|}{ Libya } \\
\hline & 0.11 & -0.19 & $0.89 * *$ & -0.59 & -0.42 & 0.56 & 0.37 & -0.80 & 0.23 \\
\hline & $(0.76)$ & $(-0.19)$ & $(2.01)$ & $(-0.32)$ & $(-0.43)$ & $(0.88)$ & $(1.00)$ & $(-0.90)$ & $(0.25)$ \\
\hline & R-squar & e: 0.28 & & & & & & & \\
\hline \multicolumn{10}{|l|}{ Oman } \\
\hline & 0.07 & 0.43 & 0.38 & -1.37 & 0.49 & -0.37 & -0.52 & $-1.27 * *$ & 0.78 \\
\hline & $(0.44)$ & $(0.38)$ & $(0.86)$ & $(-0.72)$ & $(0.44)$ & $(-0.09)$ & $(-0.32)$ & $(-6.00)$ & (3.59) \\
\hline & R-squar & e: 0.65 & & & & & & & \\
\hline \multicolumn{10}{|l|}{ Syria } \\
\hline & -0.11 & 2.14 & $1.06 * *$ & 0.42 & 0.13 & 0.15 & -0.01 & $-0.77 *$ & -0.14 \\
\hline & $(-1.07)$ & (1.12) & $(5.78)$ & $(2.03)$ & $(0.55)$ & (1.13) & $(-0.11)$ & $(-1.71)$ & $(-0.28)$ \\
\hline & R-squar & e: 0.87 & & & & & & & \\
\hline \multicolumn{10}{|l|}{ Tunisia } \\
\hline & -0.62 & 7.77 & $0.32 * *$ & 4.86 & -0.47 & 0.52 & 0.01 & -0.25 & -0.34 \\
\hline & $(-0.37)$ & $(0.43)$ & $(2.14)$ & $(0.38)$ & $(-1.40)$ & $(0.56)$ & $(0.16)$ & $(-1.32)$ & $(-1.42)$ \\
\hline & R-squar & e: 0.75 & & & & & & & \\
\hline
\end{tabular}

A0 Intercept

A1 Anticipated Change in Real GDP

A2 Unanticipated Change in Real GDP

A3 Anticipated Change in Real Interest Rate

A4 Unanticipated Change in Real Interest Rate

A5 Anticipated Change in Real Exchange Rate

A6 Unanticipated Change in Real Exchange Rate

A7 Error Correction

RH0 Serial correlation

** Significant at $5 \%$.

* Significant at $10 \%$.

t-ratios are in parenthesis 
Table 3A: Nonlinear 3SLS Parameter Estimates,

Model 2A: Nominal Consumption as a function of Nominal GDP, Nominal Interest Rate and Nominal exchange rate.

\begin{tabular}{|c|c|c|c|c|c|c|c|c|c|}
\hline & B0 & B1 & B2 & B3 & B4 & A5 & A6 & A7 & RH0 \\
\hline Egypt & $\begin{array}{l}0.05 \\
(0.72) \\
\text { R-squai }\end{array}$ & $\begin{array}{c}0.63 \\
(1.32) \\
e: 0.68\end{array}$ & $\begin{array}{c}0.31 * \\
(1.84)\end{array}$ & $\begin{array}{l}0.46 * * \\
(2.10)\end{array}$ & $\begin{array}{l}-0.54 * * \\
(-3.53)\end{array}$ & $\begin{array}{c}0.02 \\
(0.12)\end{array}$ & $\begin{array}{l}-0.12 * * \\
(-2.08)\end{array}$ & $\begin{array}{c}-0.32 \\
(-1.44)\end{array}$ & $\begin{array}{c}0.15 \\
(0.62)\end{array}$ \\
\hline$\underline{\text { Jordan }}$ & $\begin{array}{l}-0.01 \\
(-0.28) \\
\text { R-squaı }\end{array}$ & $\begin{array}{c}1.19 * * \\
(4.24) \\
\text { e: } 0.72\end{array}$ & $\begin{array}{l}0.81 * * \\
(3.12)\end{array}$ & $\begin{array}{l}-2.23 \\
(-1.01)\end{array}$ & $\begin{array}{l}-0.15 \\
(-0.61)\end{array}$ & $\begin{array}{c}-0.41 \\
(-0.92)\end{array}$ & $\begin{array}{c}-0.004 \\
(-0.02)\end{array}$ & $\begin{array}{l}-0.29 \\
(-1.51)\end{array}$ & $\begin{array}{c}-0.42 \\
(-1.52)\end{array}$ \\
\hline$\underline{\text { Pakistan }}$ & $\begin{array}{l}0.02 \\
(0.25) \\
\text { R-squar }\end{array}$ & $\begin{array}{c}1.02 * * \\
(2.60) \\
\text { e: } 0.81\end{array}$ & $\begin{array}{l}0.94 * * \\
(4.09)\end{array}$ & $\begin{array}{c}0.05 \\
(0.18)\end{array}$ & $\begin{array}{c}-0.11 \\
(-1.60)\end{array}$ & $\begin{array}{c}0.30 \\
(0.54)\end{array}$ & $\begin{array}{c}-0.08 \\
(-1.02)\end{array}$ & $\begin{array}{l}-0.88 * * \\
(-2.59)\end{array}$ & $\begin{array}{c}0.66 \\
(2.43)\end{array}$ \\
\hline
\end{tabular}

B0 Intercept

B1 Anticipated Change in Nominal GDP

B2 Unanticipated Change in Nominal GDP

B3 Anticipated Change in Nominal Interest Rate

B4 Unanticipated Change in Nominal Interest Rate

B5 Anticipated Change in Nominal Exchange Rate

B6 Unanticipated Change in Nominal Exchange Rate

B7 Error Correction

RH0 Serial correlation

** Significant at $5 \%$.

* Significant at $10 \%$.

t-ratios are in parenthesis 
Table 3B: Nonlinear 3SLS Parameter Estimates,

Model 2B: Nominal Consumption as a Function of Real GDP, Price and Nominal Exchange Rate.

\begin{tabular}{|c|c|c|c|c|c|c|c|c|c|}
\hline & B0 & B1 & B2 & B3 & B4 & A5 & A6 & A7 & RH0 \\
\hline$\underline{\text { Algeria }}$ & $\begin{array}{l}-0.02 \\
(-0.20) \\
\text { R-squar }\end{array}$ & $\begin{array}{c}-0.21 \\
(-0.15) \\
e: 0.44\end{array}$ & $\begin{array}{c}0.45 \\
(0.74)\end{array}$ & $\begin{array}{l}1.33 * * \\
(2.21)\end{array}$ & $\begin{array}{l}1.02 * * \\
(2.09)\end{array}$ & $\begin{array}{c}-0.49 \\
(-1.24)\end{array}$ & $\begin{array}{c}-0.27 \\
(-1.29)\end{array}$ & $\begin{array}{c}-0.64 * \\
(-1.68)\end{array}$ & $\begin{array}{c}0.47 \\
(1.29)\end{array}$ \\
\hline$\underline{\text { Iran }}$ & $\begin{array}{l}0.11 \\
(2.60) \\
\text { R-squar }\end{array}$ & $\begin{array}{c}0.26 \\
(1.32) \\
e: 0.71\end{array}$ & $\begin{array}{c}0.18 \\
(1.11)\end{array}$ & $\begin{array}{l}0.62 * * \\
(2.71)\end{array}$ & $\begin{array}{l}0.99 * * \\
(4.94)\end{array}$ & $\begin{array}{c}0.07 \\
(0.49)\end{array}$ & $\begin{array}{c}0.01 \\
(0.14)\end{array}$ & $\begin{array}{l}-0.34 * * \\
(-2.23)\end{array}$ & $\begin{array}{l}0.38 \\
(1.64)\end{array}$ \\
\hline Libya & $\begin{array}{l}0.04 \\
(0.25) \\
\text { R-squar }\end{array}$ & $\begin{array}{c}-0.99 \\
(-0.29) \\
\text { e: } 0.17\end{array}$ & $\begin{array}{l}0.98 * * \\
(2.11)\end{array}$ & $\begin{array}{l}1.22 \\
(0.77)\end{array}$ & $\begin{array}{c}0.83 \\
(0.94)\end{array}$ & $\begin{array}{c}-0.57 \\
(-0.88)\end{array}$ & $\begin{array}{c}-0.23 \\
(-0.66)\end{array}$ & $\begin{array}{c}-0.68 \\
(-0.75)\end{array}$ & $\begin{array}{c}0.46 \\
(0.59)\end{array}$ \\
\hline$\underline{\text { Oman }}$ & $\begin{array}{l}-0.32 \\
(-1.43) \\
\text { R-squar }\end{array}$ & $\begin{array}{c}4.45^{* *} \\
(2.61) \\
e: 0.69\end{array}$ & $\begin{array}{c}0.34 \\
(0.55)\end{array}$ & $\begin{array}{l}2.54 * \\
(2.98)\end{array}$ & $\begin{array}{c}1.73 \\
(1.52)\end{array}$ & $\begin{array}{l}-30.5 \\
(-1.09)\end{array}$ & $\begin{array}{r}2.36 \\
(1.14)\end{array}$ & & $\begin{array}{c}-0.11 \\
(-0.49)\end{array}$ \\
\hline Syria & $\begin{array}{l}-0.16 \\
(-0.77) \\
\text { R-squar }\end{array}$ & $\begin{array}{c}3.61 \\
(0.95) \\
e: 0.81\end{array}$ & $\begin{array}{l}0.82 * * \\
(2.90)\end{array}$ & $\begin{array}{c}1.07 * \\
(2.42)\end{array}$ & $\begin{array}{l}0.25 \\
(0.87)\end{array}$ & $\begin{array}{c}0.16 \\
(0.87)\end{array}$ & $\begin{array}{r}0.02 \\
(0.11)\end{array}$ & $\begin{array}{c}-0.86^{*} \\
(-1.91)\end{array}$ & $\begin{array}{c}0.39 \\
(0.83)\end{array}$ \\
\hline$\underline{\text { Tunisia }}$ & $\begin{array}{l}-0.10 \\
(-0.52) \\
\text { R-squar }\end{array}$ & $\begin{array}{c}5.06 \\
(1.23) \\
e: 0.73\end{array}$ & $\begin{array}{l}0.60 * * \\
(3.55)\end{array}$ & $\begin{array}{l}-1.45 \\
(-0.37)\end{array}$ & $\begin{array}{c}0.70 * \\
(1.72)\end{array}$ & $\begin{array}{c}-1.54 \\
(-0.69)\end{array}$ & $\begin{array}{c}-0.13 * \\
(-1.95)\end{array}$ & & $\begin{array}{l}-0.51 * * \\
(-2.48)\end{array}$ \\
\hline
\end{tabular}

B0 Intercept

B1 Anticipated Change in Real GDP

B2 Unanticipated Change in Real GDP

B3 Anticipated Change in Price

B4 Unanticipated Change in Price

B5 Anticipated Change in Nominal Exchange Rate

B6 Unanticipated Change in Nominal Exchange Rate

B7 Error Correction

RH0 Serial correlation

** Significant at $5 \%$.

* Significant at $10 \%$.

t-ratios are in parenthesis 
Table 4: Nonlinear 3SLS Parameter Estimates,

Model 3: Real Consumption as a function of Real Government Spending, Nominal Money, and Real Exchange Rate

\begin{tabular}{|c|c|c|c|c|c|c|c|c|c|}
\hline & $\mathrm{CO}$ & $\mathrm{C} 1$ & $\mathrm{C} 2$ & C3 & $\mathrm{C} 4$ & $\mathrm{C} 5$ & C6 & $\mathrm{C} 7$ & RH0 \\
\hline \multicolumn{10}{|c|}{ Algeria } \\
\hline & -0.13 & 0.64 & -0.12 & 0.84 & -0.11 & 0.02 & $0.50 * *$ & -0.50 & 0.35 \\
\hline & $(-0.30)$ & $(0.35)$ & $(-0.44)$ & $(0.33)$ & $(-0.30)$ & $(0.03)$ & $(2.12)$ & $(-0.85)$ & $(0.52)$ \\
\hline & R-squar & e: 0.20 & & & & & & & \\
\hline \multicolumn{10}{|l|}{ Egypt } \\
\hline & 0.06 & -0.11 & $0.15 * *$ & -0.05 & -0.08 & 0.13 & 0.12 & & -0.02 \\
\hline & $(1.66)$ & $(-0.62)$ & $(2.03)$ & $(-0.26)$ & $(-0.58)$ & $(0.50)$ & $(1.50)$ & & $(-0.07)$ \\
\hline & R-squar & e: 0.12 & & & & & & & \\
\hline \multicolumn{10}{|c|}{ 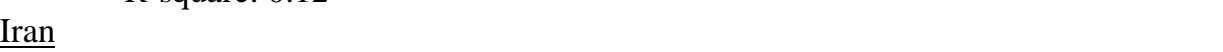 } \\
\hline & 0.06 & 1.23 & 0.09 & -0.32 & $-0.49 * *$ & 0.23 & $0.33 * *$ & -0.34 & 0.01 \\
\hline & $(0.18)$ & $(0.88)$ & $(0.71)$ & $(-0.19)$ & $(-2.02)$ & $(0.88)$ & $(3.18)$ & $(-1.33)$ & $(0.02)$ \\
\hline & R-squar & e: 0.41 & & & & & & & \\
\hline \multicolumn{10}{|c|}{ Jordan } \\
\hline & -0.05 & 0.33 & -0.16 & 0.55 & $-0.97 * *$ & 0.10 & $0.71 * *$ & -0.39 & 0.25 \\
\hline & $(-0.52)$ & $(0.94)$ & $(-1.10)$ & $(0.90)$ & $(-2.41)$ & $(0.22)$ & $(2.01)$ & $(-1.26)$ & $(0.64)$ \\
\hline & R-squar & e: 0.42 & & & & & & & \\
\hline \multicolumn{10}{|l|}{ Libya } \\
\hline & -0.39 & -1.48 & 0.36 & 1.21 & -0.15 & 0.22 & 0.04 & -0.39 & -0.34 \\
\hline & $(-1.29)$ & $(-0.37)$ & $(1.50)$ & $(1.34)$ & $(-0.64)$ & (1.17) & $(0.16)$ & $(-1.29)$ & $(-1.12)$ \\
\hline & R-squar & e: 0.55 & & & & & & & \\
\hline \multicolumn{10}{|l|}{ Oman } \\
\hline & 0.08 & -1.34 & 0.40 & -0.16 & $-0.48 *$ & -0.91 & -1.57 & $-1.28 * *$ & 0.75 \\
\hline & $(0.51)$ & $(-0.58)$ & $(1.59)$ & $(-0.26)$ & $(-1.79)$ & $(-0.47)$ & $(-1.32)$ & $(-5.25)$ & $(3.31)$ \\
\hline & R-squar & e: 0.74 & & & & & & & \\
\hline \multicolumn{10}{|c|}{ Pakistan } \\
\hline & -0.02 & 2.97 & 0.12 & -0.81 & 0.05 & -1.38 & 0.03 & $-0.43^{*}$ & 0.05 \\
\hline & $(-0.10)$ & $(0.65)$ & $(1.24)$ & $(-0.90)$ & $(0.21)$ & $(-0.72)$ & $(0.40)$ & $(-1.70)$ & $(0.14)$ \\
\hline & R-squal & e: 0.42 & & & & & & & \\
\hline \multicolumn{9}{|l|}{ Syria } & \\
\hline & 0.03 & -0.01 & 0.11 & 0.15 & $1.04 * *$ & 0.32 & -0.16 & $-0.97^{*}$ & 0.20 \\
\hline & $(0.21)$ & $(-0.02)$ & $(0.62)$ & $(0.17)$ & $(2.15)$ & $(0.80)$ & $(-1.48)$ & $(-1.97)$ & $(0.50)$ \\
\hline & R-squar & e: 0.52 & & & & & & & \\
\hline \multicolumn{10}{|c|}{ Tunisia } \\
\hline & 0.11 & $1.12 *$ & $0.27 *$ & -0.87 & 0.15 & 0.95 & 0.07 & -0.23 & -0.10 \\
\hline & (1.19) & $(2.01)$ & $(1.86)$ & $(-1.22)$ & $(0.67)$ & $(0.43)$ & $(0.63)$ & $(-1.01)$ & $(-0.37)$ \\
\hline & R-squar & e: 0.45 & & & & & & & \\
\hline
\end{tabular}

C0 Intercept

C1 Anticipated Real Government Spending

C2 Unanticipated Real Government Spending

C3 Anticipated money

C4 Unanticipated Money

C5 Anticipated Real Exchange Rate

C6 Unanticipated Real Exchange Rate

C9 Error Correction

RH0 Serial correlation

** Significant at 5\%.

* Significant at $10 \%$.

$\mathrm{t}$-ratios are in parenthesis 
Table 5: Nonlinear 3SLS Parameter Estimates,

Model 4: Nominal Consumption as a function of Nominal Government Spending, Nominal Money, and Nominal Exchange Rate

\begin{tabular}{|c|c|c|c|c|c|c|c|c|c|}
\hline & D0 & D1 & D2 & D3 & D4 & D5 & D6 & D7 & RH0 \\
\hline \multicolumn{10}{|c|}{ Algeria } \\
\hline & -0.05 & 1.07 & -0.03 & 0.12 & -0.06 & -0.07 & -0.23 & -0.38 & 0.59 \\
\hline & $(-0.17)$ & $(0.65)$ & $(-0.15)$ & $(0.09)$ & $(-0.22)$ & $(-0.05)$ & $(-1.21)$ & $(-0.67)$ & $(1.10)$ \\
\hline & R-squar & e: 0.40 & & & & & & & \\
\hline \multicolumn{10}{|l|}{ Egypt } \\
\hline & $0.13^{*}$ & $-0.31 * *$ & $-0.18 * *$ & 0.27 & 0.03 & -0.06 & $-0.22 * *$ & -0.20 & $0.78 * *$ \\
\hline & $(2.23)$ & $(-2.18)$ & $(-2.02)$ & (1.10) & $(0.23)$ & $(-0.45)$ & $(-2.77)$ & $(-1.43)$ & $(4.29)$ \\
\hline & R-squar & 0.63 & & & & & & & \\
\hline \multicolumn{10}{|l|}{ Iran } \\
\hline & -0.15 & 1.32 & 0.06 & 0.69 & 0.15 & 0.36 & $0.11 *$ & & 0.09 \\
\hline & $(-0.46)$ & $(0.89)$ & $(0.84)$ & $(0.96)$ & $(0.67)$ & $(0.87)$ & $(1.73)$ & & $(0.45)$ \\
\hline & R-squal & e: 0.49 & & & & & & & \\
\hline \multicolumn{10}{|c|}{ Jordan } \\
\hline & -0.37 & 0.14 & -0.19 & $1.14 * *$ & 0.03 & 0.08 & 0.38 & -0.37 & 0.16 \\
\hline & $(-1.25)$ & $(0.51)$ & $(-1.07)$ & $(2.07)$ & $(0.05)$ & $(0.16)$ & $(1.40)$ & $(-1.25)$ & $(0.37)$ \\
\hline & R-squar & e: 0.65 & & & & & & & \\
\hline \multicolumn{10}{|l|}{ Libya } \\
\hline & 0.01 & $0.97 * *$ & 0.02 & 0.20 & -0.05 & -0.03 & -0.19 & $-0.32 *$ & -0.16 \\
\hline & $(0.18)$ & $(2.38)$ & $(0.08)$ & $(0.42)$ & $(-0.21)$ & $(-0.08)$ & $(-0.89)$ & $(-1.82)$ & $(-0.59)$ \\
\hline & R-squar & e: 0.66 & & & & & & & \\
\hline \multicolumn{10}{|l|}{ Oman } \\
\hline & -0.18 & 0.41 & $0.66^{*}$ & $2.18 *$ & -0.18 & -5.69 & 1.01 & -0.14 & -0.19 \\
\hline & $(-1.14)$ & $(0.55)$ & $(2.01)$ & (1.93) & $(-0.52)$ & $(-0.94)$ & $(0.73)$ & $(-0.59)$ & $(-0.64)$ \\
\hline \multirow{2}{*}{\multicolumn{10}{|c|}{$\underline{\text { Pakistan }}$}} \\
\hline & & & & & & & & & \\
\hline & $0.25^{*}$ & -0.11 & 0.20 & -0.25 & 0.36 & 1.06 & 0.03 & $-0.62 *$ & 0.58 \\
\hline & (1.73) & $(-0.19)$ & $(1.46)$ & $(-0.47)$ & (1.07) & (1.05) & $(0.24)$ & $(-1.72)$ & (1.64) \\
\hline & R-squas & e: 0.59 & & & & & & & \\
\hline \multicolumn{10}{|l|}{ Syria } \\
\hline & -0.02 & 0.27 & 0.33 & 0.74 & -0.46 & 0.02 & -0.62 & $-0.73 *$ & -0.15 \\
\hline & $(-0.14)$ & $(0.46)$ & $(1.25)$ & $(0.68)$ & $(-0.80)$ & $(0.05)$ & $(-3.89)$ & $(-1.90)$ & $(-0.40)$ \\
\hline & R-squar & e: 0.47 & & & & & & & \\
\hline \multicolumn{10}{|c|}{ Tunisia } \\
\hline & 0.12 & $0.80 * *$ & $0.26 *$ & -0.77 & $0.77 * *$ & 0.32 & -0.12 & $-0.46^{*}$ & -0.13 \\
\hline & $(1.40)$ & $(2.29)$ & $(1.98)$ & $(-1.05)$ & $(3.22)$ & $(0.54)$ & $(-1.27)$ & $(-2.00)$ & $(-0.49)$ \\
\hline & R-squar & e: 0.40 & & & & & & & \\
\hline
\end{tabular}

D0 Intercept

D1 Anticipated Nominal Government Spending

D2 Unanticipated Nominal Government Spending

D3 Anticipated money

D4 Unanticipated Money

D5 Anticipated Nominal Exchange Rate

D6 Unanticipated Nominal Exchange Rate

D7 Error Correction

RH0 Serial correlation

** Significant at $5 \%$.

* Significant at $10 \%$.

$\mathrm{t}$-ratios are in parenthesis 
Table A1: The KPSS Statistics for Null of Level Stationary.

(The $5 \%$ critical value is 0.463 )

LM Statistic (Bandwidth) $^{+}$

\section{Real Consumption}

$\begin{array}{ll}\text { Algeria } & 0.76(5) \\ \text { Egypt } & 0.76(5) \\ \text { Iran } & 0.75(5) \\ \text { Jordan } & 0.64(5) \\ \text { Libya } & 0.69(5) \\ \text { Oman } & 0.67(5) \\ \text { Pakistan } & 0.77(5) \\ \text { Syria } & 0.73(5) \\ \text { Tunisia } & 0.78(5)\end{array}$

Nominal Consumption

$\begin{array}{ll}\text { Algeria } & 0.78(5) \\ \text { Egypt } & 0.76(5) \\ \text { Iran } & 0.77(5) \\ \text { Jordan } & 0.66(5) \\ \text { Libya } & 0.75(5) \\ \text { Oman } & 0.64(5) \\ \text { Pakistan } & 0.77(5) \\ \text { Syria } & 0.73(5) \\ \text { Tunisia } & 0.78(5)\end{array}$

Test description:

The KPSS (Kwiatowski, Phillips, Schmidt, and Shin) stationarity test procedure examines the null hypothesis of stationarity of a univariate time series. The KPSS test assumes that a time series variable $X_{t}$ could be decomposed into the sum of a deterministic trend, a random walk, and a stationary error. Then the random walk term is assumed to have two components: an anticipated component and an error term. The stationarity of the error term is established by testing if the variance of the error is zero.

If the calculated lag truncation variable is greater than 0.463 , we reject the null hypothesis of stationarity.

+ Bandwidth is specified using Newey-West using Bartlett Kernel. For detail see Newey-West (1994). 
Table A2: Cointegration Test Results

ADF test statistics for the null hypothesis of non-stationary residuals.

Critical value at $10 \%=-2.61$

Model 1-A: Cointegration regression includes Real Consumption, Real GDP, Real Interest Rate, and Real Exchange Rate.

$\begin{array}{ll} & \text { t-Statistic (\# of Lags) } \\ \text { Egypt } & -3.90 *(0) \\ \text { Jordan } & -5.91 *(0) \\ \text { Pakistan } & -3.41 *(0)\end{array}$

Model 1-B: Cointegration regression includes Real Consumption, Real GDP, Price, and Real Exchange Rate.

$\begin{array}{ll} & \text { t-Statistic } \\ \text { Algeria } & -2.61 *(0) \\ \text { Iran } & -3.35^{*}(0) \\ \text { Libya } & -3.97 *(0) \\ \text { Oman } & -3.68 *(0) \\ \text { Syria } & -6.68 *(0) \\ \text { Tunisia } & -4.74 *(4)\end{array}$

Model 2-A: Cointegration regression includes Nominal Consumption, Nominal GDP, Nominal Interest

Rate and Nominal Exchange Rate.

$\begin{array}{ll} & \text { t-Statistic } \\ \text { Egypt } & -4.21 *(0) \\ \text { Jordan } & -6.20^{*}(0) \\ \text { Pakistan } & -2.86^{*}(0)\end{array}$

Model 2-B: Cointegration regression includes Nominal Consumption, Real GDP, Price and Nominal Exchange Rate.

$\begin{array}{ll}\text { Algeria } & \text { t-Statistic } \\ \text { Iran } & -3.18^{*}(1) \\ \text { Libya } & -4.24 *(1) \\ \text { Oman } & -3.48^{*}(1) \\ \text { Syria } & -2.31(0) \\ \text { Tunisia } & -4.03 *(0) \\ \end{array}$

Model 3: Cointegration regression includes Real Consumption, Real Government Spending, Nominal Money, and Real Exchange Rage

\section{$\underline{\mathrm{t}-\text { Statistic }(\# \text { of Lags) }}{ }^{+}$}

$\begin{array}{ll}\text { Algeria } & -2.78 *(0) \\ \text { Egypt } & -2.45(0) \\ \text { Iran } & -3.11 *(0) \\ \text { Jordan } & -4.28 *(0) \\ \text { Libya } & -5.31 *(0) \\ \text { Oman } & -4.05 *(0) \\ \text { Pakistan } & -2.88^{*}(0) \\ \text { Syria } & -5.71 *(0) \\ \text { Tunisia } & -2.99 *(0)\end{array}$


Table A2: Cointegration Test Results (Continued)

ADF test statistics for the null hypothesis of non-stationary residuals.

Critical value at $10 \%=-2.61$

Model 4: Cointegration regression includes: Nominal Consumption, Nominal Government Spending, Nominal Money, and Nominal Exchange Rage

t-Statistic (\# of Lags)

$\begin{array}{ll}\text { Algeria } & -3.01^{*}(0) \\ \text { Egypt } & -3.57^{*}(1) \\ \text { Iran } & -2.21(2) \\ \text { Jordan } & -4.79^{*}(0) \\ \text { Libya } & -2.92^{*}(0) \\ \text { Oman } & -3.23^{*}(0) \\ \text { Pakistan } & -2.88^{*}(2) \\ \text { Syria } & -4.70^{*}(1) \\ \text { Tunisia } & -3.50^{*}(0)\end{array}$

Test Description:

If we have $\mathrm{n}$ endogenous variables, each of which is first-order integrated (that is, each has a unit root or stochastic trend or random walk element), there can be from zero to $n-1$ linearly independent cointegrating vectors. If there is one cointegrating equation, the regression models of the text include a lag of error correction term.

To check for cointegration, we apply the ADF unit root test to the residual from the cointegration regression in which the non-stationary level of real and nominal consumption are regressed on the level of variables that enter the model.

* The results reject the null hypothesis of non-stationarity at the $10 \%$ level.

+ The numbers in parentheses represent the lag lengths. The lag length is selected based on Schwartz

Information Criteria (SCI) out of max lag of 12) 
Table A3: The Results of Endogeneity Tests.

Model 1-A: Cointegration regression includes Real Consumption, Real GDP, Real Interest Rate, and Real Exchange Rate.

\begin{tabular}{|c|c|c|c|}
\hline \multirow{2}{*}{ Egypt } & \multicolumn{3}{|c|}{ Forecasted Variables } \\
\hline & Dy & Dr & Drex \\
\hline Real GDP (Dy) & & 2.00 & $4.26^{*}$ \\
\hline Real Interest Rate (Dr) & 1.00 & & 0.56 \\
\hline Real Exchange Rate (Drex) & 0.09 & 0.08 & \\
\hline \multicolumn{4}{|l|}{ Jordan } \\
\hline & Dy & Dr & Drex \\
\hline Real GDP (Dy) & & 1.07 & 0.32 \\
\hline Real Interest Rate (Dr) & 0.09 & & 0.37 \\
\hline Real Exchange Rate (Drex) & 0.80 & 0.90 & \\
\hline \multicolumn{4}{|l|}{$\underline{\text { Pakistan }}$} \\
\hline & Dy & Dr & Drex \\
\hline Real GDP (Dy) & & 1.98 & 1.00 \\
\hline Real Interest Rate (Dr) & 0.40 & & 0.70 \\
\hline Real Exchange Rate (Drex) & 2.17 & 0.99 & \\
\hline
\end{tabular}

* F-value is greater than the critical value of $\mathrm{F}$ at $10 \%$. 
Table A3: The Results of Endogeneity Tests. (Continued)

Model 1-B: Cointegration regression includes Real Consumption, Real GDP, Price, and real exchange rate.

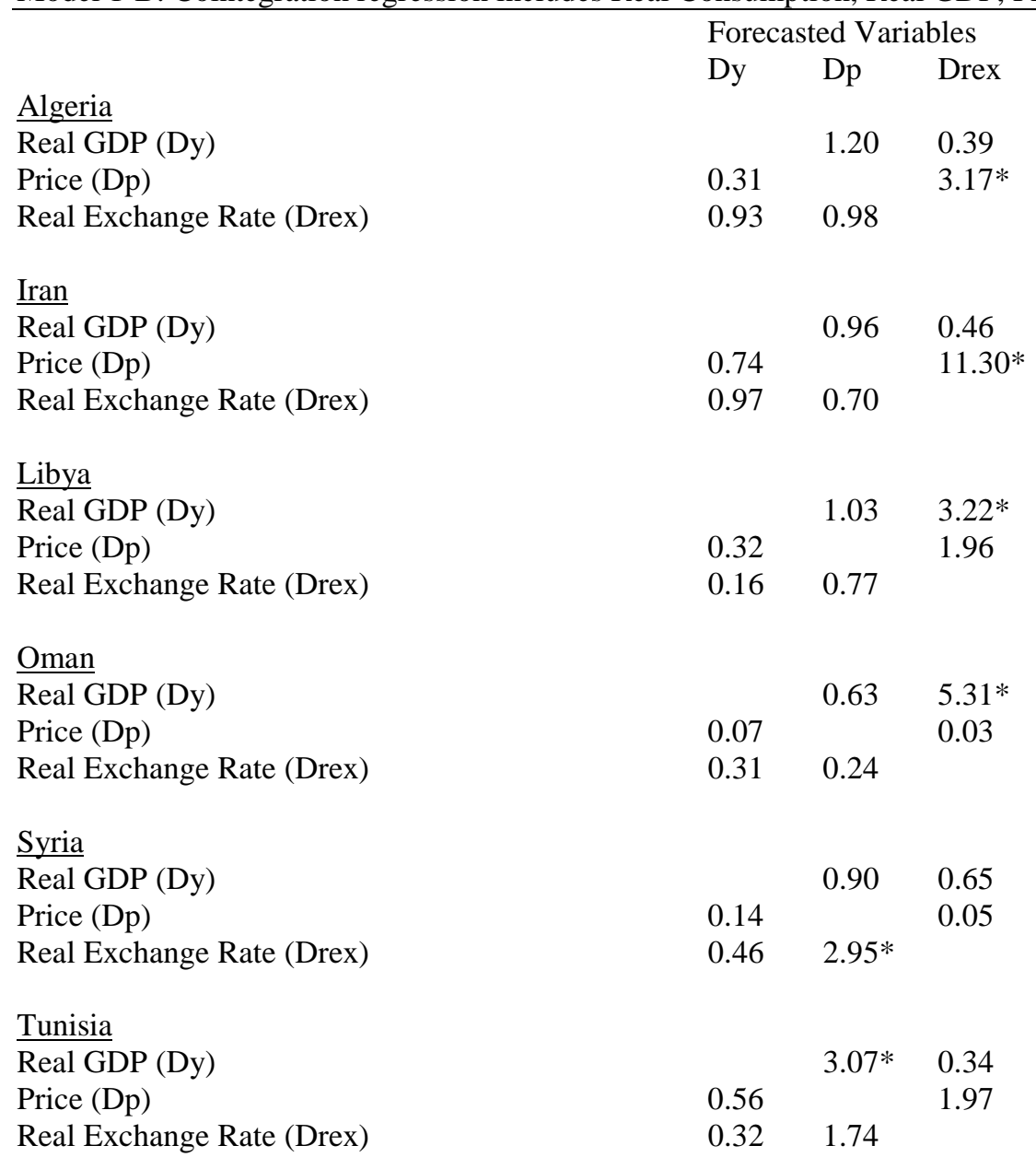

* F-value is greater than the critical value of $\mathrm{F}$ at $10 \%$. 
Table A3: The Results of Endogeneity Tests. (Continued)

Model 2A: Cointegration regression includes Nominal Consumption, Real GDP, Nominal Interest Rate, and Nominal exchange rate.

$$
\text { Forecasted Variables }
$$

Dy Di Dnex

\section{Egypt}

Nominal GDP (Dy)

Nominal Interest Rate (Di)

$\begin{array}{lll} & 0.97 & 0.76 \\ 3.39 * & & 10.24\end{array}$

Nominal Exchange Rate (Dnex)

$0.67 \quad 0.16$

$\underline{\text { Jordan }}$

Nominal GDP (Dy)

Nominal Interest Rate (Di)

Nominal Exchange Rate (Dnex)

$\begin{array}{lll} & 0.24 & 0.32 \\ 1.13 & & 1.62\end{array}$

Pakistan

Nominal GDP (Dy)

$0.47 \quad 0.51$

Nominal Interest Rate (Di)

Nominal Exchange Rate (Dnex)

$\begin{array}{lll} & 2.25 & 10.71^{*} \\ 0.11 & & 1.26 \\ 1.16 & 0.05 & \end{array}$

* F-value is greater than the critical value of $\mathrm{F}$ at $10 \%$. 
Table A3: The Results of Endogeneity Tests. (Continued)

Model 2B: Cointegration regression includes Nominal Consumption, Real GDP, Price, and Nominal exchange rate.

\begin{tabular}{|c|c|c|c|}
\hline & & & \\
\hline & & & \\
\hline Real GDP (Dy) & & 1.02 & 0.36 \\
\hline Price $(D p)$ & 0.35 & & $2.59 *$ \\
\hline Nominal Exchange Rate (Dnex) & 0.90 & 0.75 & \\
\hline Iran & & & \\
\hline Real GDP (Dy) & & 0.95 & 0.43 \\
\hline Price $(D p)$ & 0.97 & & $9.27 *$ \\
\hline Nominal Exchange Rate (Dnex) & 1.02 & $2.75^{*}$ & \\
\hline Libya & & & \\
\hline Real GDP (Dy) & & 0.15 & 2.11 \\
\hline Price $(D p)$ & 0.35 & & $3.76^{*}$ \\
\hline Nominal Exchange Rate (Dnex) & 0.27 & 1.74 & \\
\hline Oman & & & \\
\hline Real GDP (Dy) & & 2.32 & $3.17 *$ \\
\hline Price (Dp) & 0.01 & & 1.58 \\
\hline Nominal Exchange Rate (Dnex) & 0.47 & 2.46 & \\
\hline Syria & & & \\
\hline Real GDP (Dy) & & 1.54 & 0.78 \\
\hline Price $(D p)$ & 0.12 & & 0.03 \\
\hline Nominal Exchange Rate (Dnex) & 0.92 & $15.34^{*}$ & \\
\hline Tunisia & & & \\
\hline Real GDP (Dy) & & 0.11 & 2.14 \\
\hline Price $(D p)$ & 0.52 & & $2.89^{*}$ \\
\hline Nominal Exchange Rate (Dnex) & 0.24 & $3.50 *$ & \\
\hline
\end{tabular}

* F-value is greater than the critical value of $\mathrm{F}$ at $10 \%$. 
Table A3: The Results of Endogeneity Tests. (Continued)

Model 3: Cointegration regression includes Real Consumption, Real Government Spending, Nominal Money, and Real Exchange Rage

\begin{tabular}{|c|c|c|c|}
\hline \multirow[b]{3}{*}{ Algeria } & \multicolumn{3}{|c|}{ Forecasted Variables } \\
\hline & $\mathrm{Dm}$ & $\mathrm{Dg}$ & Drex \\
\hline & & & \\
\hline Nominal Money Supply (Dm) & & 0.30 & 0.01 \\
\hline Real Government Spending (Dg) & 0.96 & & 0.28 \\
\hline Real Exchange Rate (Drex) & 0.13 & 1.09 & \\
\hline \multicolumn{4}{|l|}{ Egypt } \\
\hline Nominal Money Supply (Dm) & & $4.32 *$ & 0.98 \\
\hline Real Government Spending (Dg) & 1.00 & & $4.57 *$ \\
\hline Real Exchange Rate (Drex) & 0.22 & 0.16 & \\
\hline \multicolumn{4}{|l|}{$\underline{\text { Iran }}$} \\
\hline$\overline{\text { Nominal Money Supply (Dm) }}$ & & 1.04 & 0.93 \\
\hline Real Government Spending (Dg) & 1.43 & & 2.03 \\
\hline Real Exchange Rate (Drex) & 0.74 & 0.18 & \\
\hline \multicolumn{4}{|l|}{ Jordan } \\
\hline Nominal Money Supply (Dm) & & 0.87 & 0.56 \\
\hline Real Government Spending (Dg) & 1.63 & & 0.34 \\
\hline Real Exchange Rate (Drex) & 0.31 & 2.04 & \\
\hline \multicolumn{4}{|l|}{ Libya } \\
\hline Nominal Money Supply (Dm) & & 0.75 & 0.19 \\
\hline Real Government Spending (Dg) & 1.30 & & 0.14 \\
\hline Real Exchange Rate (Drex) & 1.50 & 1.43 & \\
\hline \multicolumn{4}{|l|}{ Oman } \\
\hline$\overline{\text { Nominal Money Supply (Dm) }}$ & & 1.96 & $4.43^{*}$ \\
\hline Real Government Spending (Dg) & 0.96 & & 1.40 \\
\hline Real Exchange Rate (Drex) & 0.01 & 0.27 & \\
\hline \multicolumn{4}{|l|}{ Pakistan } \\
\hline Nominal Money Supply (Dm) & & 2.08 & $5.75^{*}$ \\
\hline Real Government Spending (Dg) & 0.11 & & 0.08 \\
\hline Real Exchange Rate (Drex) & 0.79 & $3.19 *$ & \\
\hline \multicolumn{4}{|l|}{ Syria } \\
\hline Nominal Money Supply (Dm) & & 0.07 & 0.03 \\
\hline Real Government Spending (Dg) & 0.44 & & 0.48 \\
\hline Real Exchange Rate (Drex) & 0.33 & 0.99 & \\
\hline \multicolumn{4}{|l|}{ Tunisia } \\
\hline Nominal Money Supply (Dm) & & 0.82 & 1.82 \\
\hline Real Government Spending (Dg) & 0.85 & & 1.29 \\
\hline Real Exchange Rate (Drex) & 1.69 & 0.75 & \\
\hline
\end{tabular}

F-value is greater than the critical value of $\mathrm{F}$ at $10 \%$. 
Table A3: The Results of Endogeneity Tests.

Model 4: Cointegration regression includes: Nominal Consumption, Nominal Government Spending, Nominal Money, and Nominal Exchange Rage

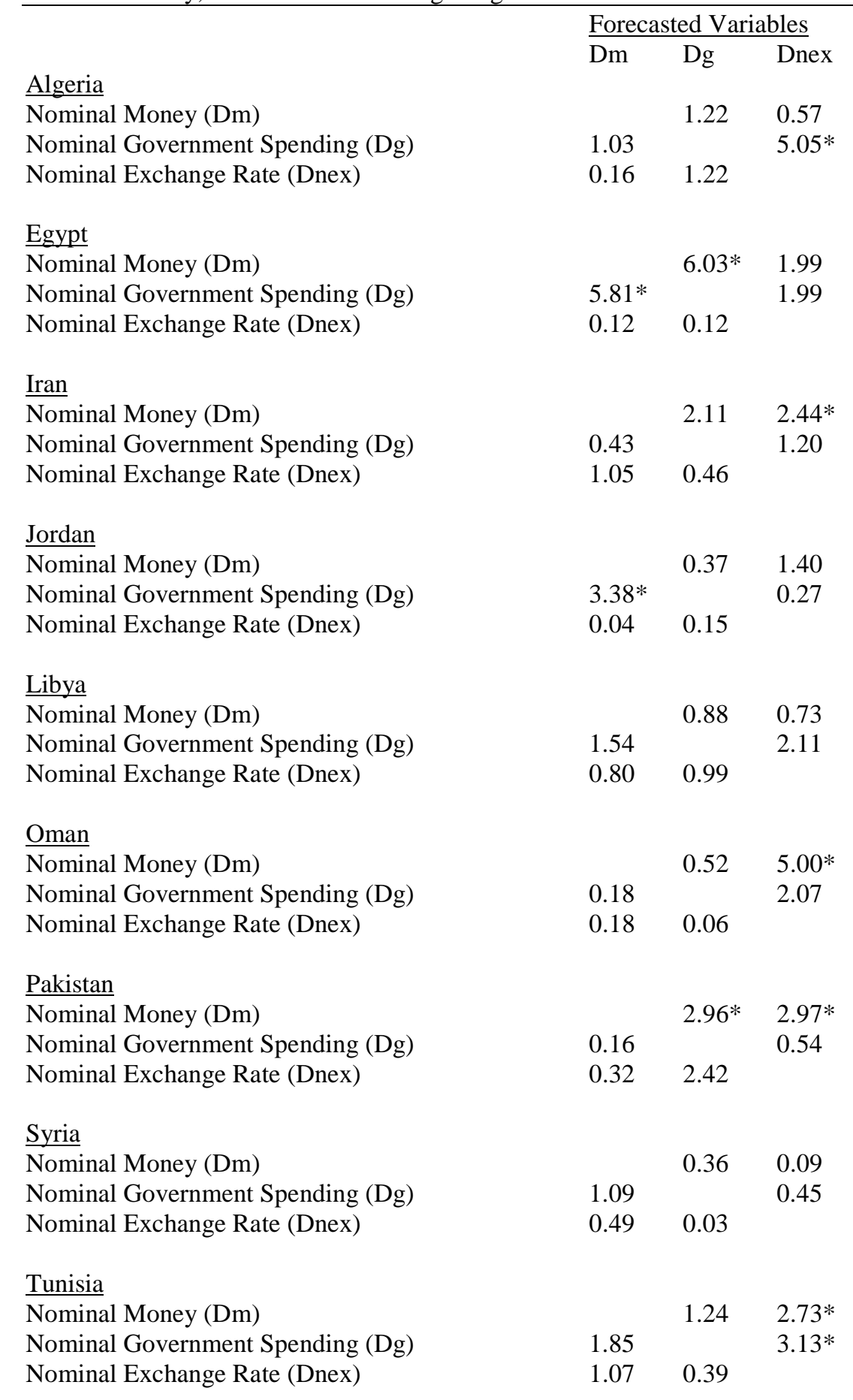

* F-value is greater than the critical value of $\mathrm{F}$ at $10 \%$. 